Article

\title{
Ex-Vivo Trans-Corneal and Trans-Scleral Diffusion Studies with Ocular Formulations of Glutathione as an Antioxidant Treatment for Ocular Diseases
}

\author{
María Sebastián-Morelló ${ }^{\circledR}$, Adrián M. Alambiaga-Caravaca ${ }^{\circledR}$, María Aracely Calatayud-Pascual, \\ Vicent Rodilla * (1) , Cristina Balaguer-Fernández, María Miranda and Alicia López-Castellano *(1) \\ Facultad de Ciencias de la Salud, Instituto de Ciencias Biomédicas, Universidad Cardenal Herrera-CEU, \\ CEU Universities, C/Santiago Ramón y Cajal, s/n., Alfara del Patriarca, 46115 Valencia, Spain; \\ maria.sebastian@uchceu.es (M.S.-M.); adrian.alambiagacaravaca@uchceu.es (A.M.A.-C.); \\ maria.calatayud@uchceu.es (M.A.C.-P.); cbalaguer@uchceu.es (C.B.-F.); mmiranda@uchceu.es (M.M.) \\ * Correspondence: vrodilla@uchceu.es (V.R.); alopez@uchceu.es (A.L.-C.); Tel.: +34-961-369-00 (ext. 64527) (V.R.); \\ +34-961-369-00 (ext. 64427) (A.L.-C.)
}

Received: 6 August 2020; Accepted: 7 September 2020; Published: 10 September 2020

\begin{abstract}
Exposure to sunlight and contact with atmospheric oxygen makes the eye particularly susceptible to oxidative stress, which can potentially produce cellular damage. In physiological conditions, there are several antioxidant defense mechanisms within the eye. Glutathione (GSH) is the most important antioxidant in the eye; GSH deficit has been linked to several ocular pathologies. The aim of this study was to explore the potential for newly developed formulations allowing controlled delivery of antioxidants such as GSH and vitamin C (Vit C) directly to the eye. We have investigated the stability of antioxidants in aqueous solution and assessed ex-vivo the diffusion of GSH through two ocular membranes, namely cornea and sclera, either in solution or included in a semisolid insert. We have also carried out the hen's egg-chlorioallantoic membrane test (HET-CAM) to evaluate the ocular irritancy of the different antioxidant solutions. Our results showed that GSH is stable for up to 30 days at $4{ }^{\circ} \mathrm{C}$ in darkness and it is not an irritant to the eye. The diffusion studies revealed that the manufactured formulation, a semisolid insert containing GSH, could deliver this tripeptide directly to the eye in a sustained manner.
\end{abstract}

Keywords: glutathione; antioxidants; ocular drug delivery; hen's egg-choriollantoic membrane test (HET-CAM); ocular diffusion studies

\section{Introduction}

Oxidative stress was defined by Helmut Sies as "a change in the prooxidant-antioxidant balance in favor of the former" [1]. Oxidative stress stimulates the production of highly reactive oxygen species (ROS), potentially leading to cellular damage. Our eyes are especially susceptible to oxidative stress because they are greatly exposed to sunlight and atmospheric oxygen [2]. Indeed, alterations in the cellular redox state within the eye are believed to contribute to the pathogenesis of many ocular diseases [3].

Under normal physiological conditions, ocular tissues have several intrinsic antioxidants to overcome the oxidative stress generated as a result of normal cell metabolism. The two key antioxidants in the eye are glutathione (GSH) and vitamin C (Vit C) [4]. While ascorbic acid (Vit C) is found in the corneal epithelium, GSH is found mainly in the lens $[5,6]$.

Vit $C$ is one of the most important antioxidants in the cornea [7] and as it is neither synthesized nor stored in the human body, dietary intake is essential to maintain its adequate levels. Vit $C$ is also found in high concentrations in the aqueous humor [4]. Dietary intake of antioxidants like Vit C has been 
associated with protective effects against the incidence of three major eye diseases linked to oxidative stress: cataracts, age-related macular degeneration, and glaucoma [8].

GSH is a tripeptide of L-glutamate, L-cysteine, and glycine [9], and is considered the most important intracellular endogenous antioxidant in living organisms and the first line of defense against oxidative stress. GSH exists in the form of reduced thiol (GSH) and oxidized disulfide (GSSG) [10]. GSH is formed in a two-step enzymatic process including, first, the formation of $\gamma$-glutamylcysteine from glutamate and cysteine (Cys), a reaction catalyzed by the enzyme $\gamma$-glutamylcysteine synthetase; and second, GSH synthetase (GS) intervenes to catalyze the condensation of $\gamma$-glutamylcysteine and glycine to generate GSH [11].

GSH levels in the eyes are maintained by a combination of GSH dietary uptake, de novo synthesis from its precursor amino acids, GSH regeneration from GSSG, and GSH transport [4]. The transport of GSH through membranes is regulated by transporters and occurs according to a concentration gradient; however, the regulatory mechanisms of those GSH transporters are still not well understood [12].

Deficit in GSH has been linked to retinal pathologies. The retina has a high need for antioxidant protection because it is exposed to high oxygen pressure (oxygen consumption in the retina is the highest among all human tissues) as well as UV and blue light. As photoreceptor membranes are rich in polyunsaturated fatty acids which are readily oxidized and there is a complex choroidal blood flow autoregulation, antioxidant protection is of utmost importance [13]. In the retina, Müller cells produce GSH but with age, production of GSH is reduced. This is related to mitochondrial damage, reduced cell viability, and progression of several retinopathies in the elderly, such as diabetic retinopathy, glaucoma, or age-related macular degeneration [14]. Alterations in GSH metabolism have also been linked to hereditary retinal degenerations such as retinitis pigmentosa [15]. GSH is also directly associated with cataract development. It is known that with increasing age, GSH in the lens nucleus decreases and the lens may become more susceptible to cataract formation [16].

As GSH has poor bioavailability, interventions aimed to increase GSH concentrations in different tissues have relied on administration of GSH, monoesters, or alternative precursors [17].

It has been known for years that GSH import in mammals involved its extracellular degradation, uptake of its constituents, and re-synthesis inside the cells. However, the existence of specific transporters for GSH has been demonstrated in different tissues [18]. Several studies have reported the beneficial effect of direct oral or nasal GSH administration in inflammation, alterations of the immune system, or Parkinson's disease [19-21]. In addition, it has been shown that oral administration of antioxidant mixtures containing GSH were able to reduce photoreceptor cell death in an animal model of retinitis pigmentosa [22,23]. All this evidence supports the possible beneficial effects of GSH administered directly to ocular tissues.

The most common route for drug administration to the eyes is topical administration, as application is easy, patient compliance is high, and dosage and secondary effects are minimized [24]. However, due to the eye's inherent anatomical and physiological barriers, diffusion of drugs topically applied to the eye is very poor [25]. Typically, drug bioavailability is estimated to be less than $5 \%$ of the drug administrated by drop instillation [25].

Ocular inserts are solid or semisolid devices that can deliver drugs to the eye [26,27]. These inserts provide accurate dosing, reduced systemic diffusion, and in some cases, better patient compliance due to reduced administration frequency and lower incidence of visual and systemic side effects [28,29]. Furthermore, ophthalmic inserts may facilitate drug diffusion and efficacy as permanence of the drug in the surface of the eye becomes increased.

The aim of this study was to evaluate the potential for developing formulations allowing controlled delivery of antioxidants such as GSH and Vit C directly to the eye. The study assessed the stability of antioxidants (GSH and Vit C) in aqueous solution and evaluated their ocular irritancy. Furthermore, the potential of ocular antioxidant formulations was assessed by diffusion studies of GSH through cornea and sclera, either from solution or from a purposely manufactured semisolid insert. 


\section{Materials and Methods}

\subsection{Reagents}

Most chemicals (GSH, Vit C, iodoacetic acid, potassium hydroxide $(\mathrm{KOH})$, potassium bicarbonate $\left(\mathrm{KHCO}_{3}\right)$ 1-fluoro-2,4-dinitrobencene (DNFB), disodium hydrogen phosphate, sodium dihydrogen phosphate, sodium chloride, and bidestilled water) were purchased from Sigma-Aldrich (Madrid, Spain). Acros Organics (Morris Plains, NJ, USA) supplied m-cresol, and perchloric acid (PCA) was obtained from Panreac (Barcelona, Spain).

Phosphate buffered solution (PBS) was prepared in the laboratory and its $\mathrm{pH}$ adjusted to $7.5 \pm 0.1$ with hydrochloric acid $(\mathrm{HCl}) 5 \mathrm{~N}$ or sodium hydroxide $(\mathrm{NaOH}) 5 \mathrm{~N}$.

Most reagents for high performance liquid chromatography (HPLC) (methanol, water, and glacial acetic acid) were purchased from J.T. Baker ${ }^{\circledR}$ (Deventer, Netherlands), but sodium acetate was purchased from Sigma-Aldrich (Madrid, Spain).

Reagents for insert preparation (hydroxypropyl methylcellulose 4500 (HPMC), polyvinylpyrrolidone K30 (PVP-K30), polyethylene glycol (PEG) and glycerol) were supplied by Guinama (Valencia, Spain).

\subsection{Ocular Tolerance Test (HET-CAM Test) Fertile}

Fertile eggs from White Leghorn hens were supplied by Granja Santa Isabel (Cordoba, Spain) and incubated at $37^{\circ} \mathrm{C}$ and $60 \%$ relative humidity. Eggs were incubated in an incubator (Covatutto 24 digitale, Novital S.r.l, Lonate Pozzolo, Italy) coupled to an egg turner (Girauova automatic, Novital S.r.l, Lonate Pozzolo, Italy) which automatically rotated the eggs to ensure correct embryo development. After being incubated for 8 days, a circular cut was made on the eggshell using a rotatory saw. After moistening the inner membrane with a $0.9 \% \mathrm{NaCl}$ solution, this was carefully removed to expose the chorioallantoic membrane (CAM). Aliquots $(300 \mu \mathrm{L})$ of GSH $(5 \mathrm{mg} / \mathrm{mL}$ and $10 \mathrm{mg} / \mathrm{mL}$, and $5 \mathrm{mg} / \mathrm{mL}$ GSH with $3 \mathrm{mg} / \mathrm{mL}$ Vit C) were placed on the CAM of different eggs. Negative and positive controls were solutions of $0.9 \% \mathrm{NaCl}$ and $0.1 \mathrm{~N} \mathrm{NaOH}$, respectively. Irritation score (IS) was calculated (1) by monitoring and recording the time of appearance of each of the following endpoints: hemorrhage ( $\mathrm{tH}$, bleeding from the vessels), vascular lysis ( $\mathrm{tL}$, blood vessel disintegration), or coagulation ( $\mathrm{tC}$, intravascular and extravascular protein denaturation) of CAM vessels over a period of $300 \mathrm{~s}$ [30].

$$
\mathrm{IS}=\frac{(301-\mathrm{tH}) \times 5}{300}+\frac{(301-\mathrm{tL}) \times 7}{300}+\frac{(301-\mathrm{tC}) \times 9}{300}
$$

The values of damage were classified by means of IS as IS $<1$ (non-irritant), $1 \leq$ IS $<5$ (mild irritant), $5 \leq$ IS $<10$ (moderately irritant), or IS $>10$ (severe irritant).

\subsection{Stability Studies of GSH}

A GSH solution in PBS (5 mg/mL) adjusted at $\mathrm{pH} 6.5$ was prepared to evaluate GSH stability in solution under different conditions. The role of Vit $\mathrm{C}$ as an antioxidant was also assessed by preparing an additional GSH solution (5 mg/mL) containing $3 \mathrm{mg} / \mathrm{mL}$ of Vit C [22].

The effects of light and temperature on the stability of GSH solutions were addressed by storing them at $4{ }^{\circ} \mathrm{C}$ and $25^{\circ} \mathrm{C}$ in darkness or under illumination and sampling and analyzing them at $0,2,7,14$, and 30 days.

\subsection{Ocular Insert with GSH}

A semisolid ocular insert using bioadhesive polymers (HPMC, PVP, and PEG) [31] with glycerol as a plasticizer and GSH in the matrix was prepared using a solvent casting method. The polymers were weighed and dissolved by gently stirring in the necessary amount of water (quantum satis, qs) (Table 1) to make a final volume of $10 \mathrm{~mL}$. The corresponding amount of glycerol was then added to the solution which was continuously stirred at room temperature for $24 \mathrm{~h}[32,33]$ before adding GSH. 
Table 1. GSH ocular semisolid insert composition.

\begin{tabular}{cc}
\hline Component & Amount \\
\hline Polyvinylpyrrolidone K30 & $600 \mathrm{mg}$ \\
Hydroxypropyl methylcellulose 4500 & $400 \mathrm{mg}$ \\
Polyethylene glycol & $0.5 \mathrm{~mL}$ \\
Water & qs for a final volume of $10 \mathrm{~mL}$ \\
Glycerol & $25 \mathrm{mg}$ \\
Glutathione & $100 \mathrm{mg}$ \\
\hline
\end{tabular}

\subsection{Ex-Vivo Ocular Diffusion Studies}

Whole eyes were obtained after sacrifice from two-month-old hybrid albino rabbits of either sex [34-36]. The eyes were immediately rinsed in saline solution and any muscle remaining attached was cut away with scissors. An incision along the sclera-limbo junction was made to obtain the cornea and sclera from each eye, which were then used as membranes for diffusion studies [36,37]. The experimental protocol was approved by the Ethical Committee of University CEU Cardenal Herrera (Ref. 2011/010) and by the Conselleria d'Agricultura, Pesca I Alimentació, Generalitat Valenciana (Ref. No. 2017/VSC/PEA/00192). Prior to sacrifice, animals were housed, fed, and handled according to current animal welfare principles (Spanish Royal Decree 1201/2005, (BOE 2005)).

GSH diffusion through cornea and sclera was assessed using vertical standard diffusion cells (Franz type) with a diffusion area of $0.567 \pm 0.008 \mathrm{~cm}^{2}$ (DISA, Milan, Italy) [38]. The membrane (i.e., cornea or sclera) was placed in the diffusion cell with the external part facing the donor compartment. The receptor compartment of the diffusion cells (in contact with the internal side of the cornea or sclera) was filled to its capacity $\left(4.2 \pm 0.1 \mathrm{~mL}\right.$ ) with PBS (pH 7.4) at $37.0 \pm 0.1{ }^{\circ} \mathrm{C}$. To prevent possible boundary layer effects, PBS was stirred with a rotating Teflon-coated magnet. The donor compartment was filled with $0.5 \mathrm{~mL}$ of GSH solution $(5 \mathrm{mg} / \mathrm{mL}$ or $10 \mathrm{mg} / \mathrm{mL})$ or $0.5 \mathrm{~mL}$ of the previously manufactured semisolid insert of GSH $(10 \mathrm{mg} / \mathrm{mL})$.

Samples $(180 \mu \mathrm{L})$ were taken from the receptor compartment every 15 min during the first hour, and then every 30 min during the following $2 \mathrm{~h}$ [39]. Immediately after the sample was withdrawn, the volume was replaced with $180 \mu \mathrm{L}$ of PBS to ensure that sink conditions in the receptor compartment were maintained $[34,35,40]$. To ensure preservation of the sample until analysis, a $20 \mu \mathrm{L}$ volume of PCA (20\% solution) was added to each sample.

\subsection{Determination of GSH}

GSH concentration in each experimental sample was determined according to published procedures [30]. Briefly, HPLC analysis was carried out using a Gilson system (Gilson 322 pump, Gilson 150 UV/VIS detector, Gilson 864 degasser, and Gilson 234 automatic injector) (Gilson, Middleton, WI, USA). Data were acquired and processed on a Unipoint ${ }^{\mathrm{TM}}$ software system. A Kromasil ${ }^{\circledR}$ Amino $5 \mu \mathrm{m}, 250 \times 4.6 \mathrm{~mm}$ column was purchased from Análisis vínicos (Barcelona, España). All solutions were filtered using cellulose membrane filters (Sartorius Stedim Biotech (Madrid, España) with a $0.2 \mu \mathrm{m}$ pore diameter.

Mobile phase A was prepared with 80:20 methanol:water $(v / v)$ and mobile phase B was prepared with a $20 \%$ solution of sodium acetate trihydrate $4 \mathrm{M}$ and $756 \mathrm{~mL} / \mathrm{L}$ glacial acetic acid in water and $80 \%$ of phase A. Initial chromatography conditions $(1.0 \mathrm{~mL} / \mathrm{min}, 80 \%$ mobile phase A and $20 \%$ mobile phase B) were maintained for 10 min which were followed by a linear gradient to $95 \%$ mobile phase B for $40 \mathrm{~min}$. Initial chromatography conditions were then pumped through the column for $10 \mathrm{~min}$ to prepare the system for the next sample. The wavelength used was $365 \mathrm{~nm}$. The range of the UV detector used was 0.005 and the response time was $5 \mathrm{~s}$.

The stock solution for calibration (10 mM GSH in PBS) was prepared daily and stored in a refrigerator at $4{ }^{\circ} \mathrm{C}$ until required. Standards for calibration curves were prepared daily using the following GSH concentrations: $0 \mu \mathrm{M}, 20 \mu \mathrm{M}, 40 \mu \mathrm{M}, 60 \mu \mathrm{M}, 80 \mu \mathrm{M}$, and $100 \mu \mathrm{M}$. To a $180 \mu \mathrm{L}$ volume 
of each of these standards, $20 \mu \mathrm{L}$ of a $20 \%$ solution of perchloric acid was added to acidify the solution. Both samples and standards were prepared in $1.5 \mathrm{~mL}$ Eppendorf tubes and were derivatized prior to analysis, following the protocol described by Reed et al. [41].

\subsection{Data Analysis}

Data were always expressed as mean \pm SD. Data were assumed to be normally distributed and homoscedasticity was assessed with Levene's test. Homoscedastic data were statistically analyzed by means of a one-way ANOVA and post-hoc multiple comparison tests (Scheffeé). When unequal variances were present, data were analyzed using the Brown-Forsythe ANOVA and multiple comparisons were carried out using the Dunnett T3 test. For two group comparisons the Student $t$-test (homoscedastic data) or the Welch test (heteroscedasticity) were used. The level of significance was fixed at $p<0.05$.

\section{Results and Discussions}

The hen's egg test on the chorioallantoic membrane (HET-CAM) (an alternative to the in vivo Draize rabbit eye test) was carried out to assess the potential irritancy of GSH and Vit C solutions.

The HET-CAM test revealed that GSH solutions $(10 \mathrm{mg} / \mathrm{mL}, 5 \mathrm{mg} / \mathrm{mL})$ and the solution of $5 \mathrm{mg} / \mathrm{mL}$ GSH with $3 \mathrm{mg} / \mathrm{mL}$ of Vit C, did not produce hemorrhages, lysis, or coagulation (Figure 1). The IS for the negative control $(0.9 \% \mathrm{NaCl})$ and for all formulations assayed was zero. Therefore, all antioxidant solutions were considered to be non-irritant. In contrast, the IS for the positive control $(\mathrm{NaOH} 0.1 \mathrm{~N})$ was $45 \mathrm{~s}$. These results are consistent with similar studies which evaluated the irritancy of antibiotics or hormones using the HET-CAM test [42,43].

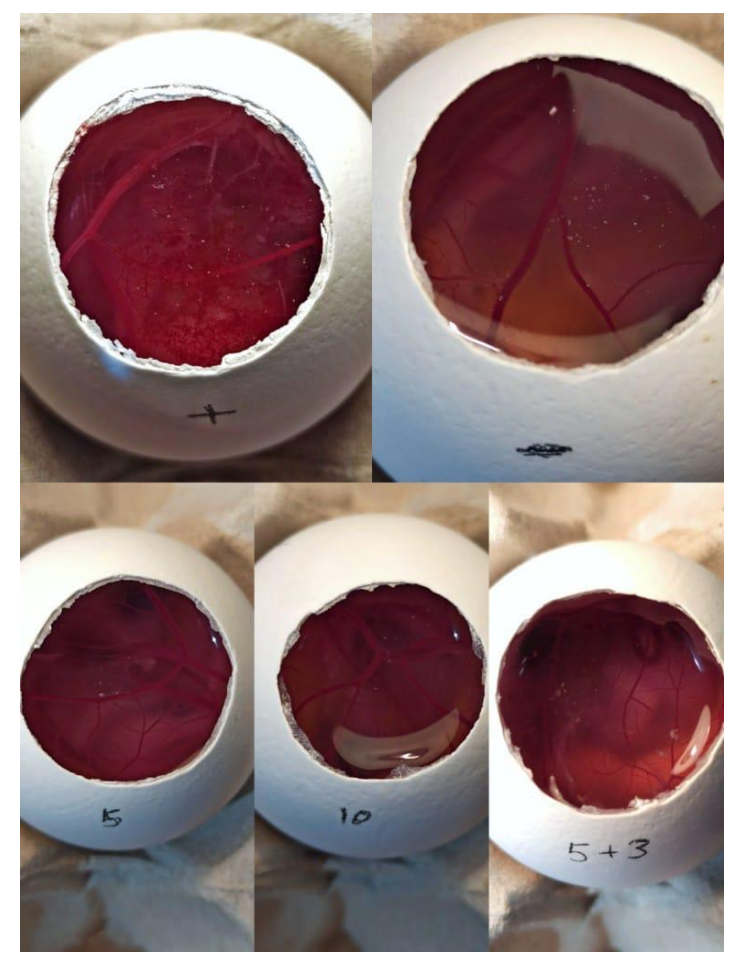

Figure 1. Photograph of the hen's egg-choriollantoic membrane test (HET-CAM) test results to evaluate the irritancy of glutathione (GSH) solutions. In clockwise direction, positive $(0.1 \mathrm{~N} \mathrm{NaOH})$ and negative $(0.9 \% \mathrm{NaCl})$ controls, $5 \mathrm{mg} / \mathrm{mL}$ and $10 \mathrm{mg} / \mathrm{mL} \mathrm{GSH}$ solutions, and $5 \mathrm{mg} / \mathrm{mL} \mathrm{GSH}$ containing $3 \mathrm{mg} / \mathrm{mL}$ Vit C.

Stability studies were carried out using two solutions: $5 \mathrm{mg} / \mathrm{mL} \mathrm{GSH}$ and $5 \mathrm{mg} / \mathrm{mL}$ GSH containing $3 \mathrm{mg} / \mathrm{mL}$ Vit C. Different preservation conditions were also studied $\left(25^{\circ} \mathrm{C}\right.$ with light exposure, $25^{\circ} \mathrm{C}$ 
in darkness and $4{ }^{\circ} \mathrm{C}$ in darkness). The results of stability experiments revealed that there were differences across times in the samples stored at room temperature for GSH and GSH with Vit C (in all cases $p$ <.001). Statistically significant lower concentrations of GSH were seen from day 7 onwards when samples were stored at room temperature. However, samples remained stable in both cases (GSH and GSH with Vit C $(p=0.176))$ for up to 30 days when stored at $4{ }^{\circ} \mathrm{C}$ in darkness $(p=0.445)$ (Table 2).

Table 2. Stability results obtained for GSH solution and GSH + Vit C solution. Concentration mean as a percentage of original concentration $\pm \mathrm{SD}(n=3)$.

\begin{tabular}{ccccc}
\hline Solutions & Day & $\mathbf{2 5}{ }^{\circ} \mathbf{C}$ Light & $\mathbf{2 5}{ }^{\circ} \mathbf{C}$ Darkness & $\mathbf{4}^{\circ} \mathbf{C}$ Darkness \\
\hline \multirow{6}{*}{ GSH } & 2 & $97.56 \pm 3.27$ & $97.30 \pm 3.95$ & $99.44 \pm 2.35$ \\
& 7 & $88.88 \pm 1.21$ & $89.37 \pm 2.26$ & $99.19 \pm 7.78$ \\
& 14 & $88.87 \pm 1.21$ & $87.44 \pm 0.45$ & $98.78 \pm 7.29$ \\
& 30 & $71.14 \pm 0.35$ & $72.92 \pm 2.71$ & $92.27 \pm 5.78$ \\
\hline GSH + Vit C & 2 & $86.81 \pm 5.09$ & $95.86 \pm 2.54$ & $96.93 \pm 8.28$ \\
& 7 & $77.17 \pm 10.16$ & $86.99 \pm 0.39$ & $94.72 \pm 6.25$ \\
& 14 & $73.87 \pm 4.81$ & $78.40 \pm 3.00$ & $91.47 \pm 4.57$ \\
\hline
\end{tabular}

GSH: glutathione. Vit C: vitamin C.

We also compared differences in stability between GSH and GSH with Vit C at different storage times for each condition. Although GSH stability decreases with time in the three storage conditions, this is more pronounced in samples stored at room temperature, either with or without light. In these cases, statistical differences are particularly seen from day 14 onwards $(p<0.05)$. However, when GSH and GSH + Vit C samples were stored at $4{ }^{\circ} \mathrm{C}$ in the dark, no statistical differences were found $(p>0.05)$ (Table 2).

In summary, these data showed that better stability was achieved when samples were stored at $4{ }^{\circ} \mathrm{C}$ in darkness, as no statistically significant differences were detected across storage time. Significantly lower levels of GSH were measured when samples were stored at room temperature. Although some studies have shown that antioxidants like vitamins $\mathrm{C}$ and $\mathrm{E}$ can compensate for low levels of GSH in the lens, thus protecting against oxidative insults [44], it seems that in our studies, Vit C is readily oxidized at room temperature $[45,46]$ and as GSH intervened non-enzymatically to reduce Vit C, lower levels of GSH were detected in these cases. The role of GSH in reducing oxidized Vit C was demonstrated as far back as 1976 by Foyer and Halliwell who showed that in absence of dehydroascorbate reductase, GSH was responsible for the reduction of dehydroascorbate back to ascorbate (Vit C) [47]. Although these data referred to chloroplasts, similar biochemical reactions have been described in other living organisms [48] and one can expect that they can also take place in the test tube, as in our case.

Following these experiments, ex-vivo diffusion studies of GSH solutions through cornea and sclera were performed. All our experiments have been carried out in freshly-obtained tissue because although sometimes diffusion studies have been carried out using frozen-thawed tissue [49,50] it has been shown that frozen tissue suffers significant histological changes which affect diffusion [36]) and that particularly with small substances (GSH is a relatively small tripeptide) higher diffusion rates across frozen-thawed tissue are observed when compared to fresh tissue [50].

There were statistically significantly differences between the accumulated amount of GSH in the receptor compartment obtained from the $10 \mathrm{mg} / \mathrm{mL}$ and $5 \mathrm{mg} / \mathrm{mL}$ solutions in ex-vivo trans-corneal diffusion studies $\left(191.89 \pm 53.44 \mu \mathrm{g} / \mathrm{cm}^{2}\right.$ and $91.29 \pm 7.97 \mu \mathrm{g} / \mathrm{cm}^{2}$, respectively; $\left.p<0.05\right)($ Figure 2). The estimated lag time $\left(\mathrm{t}_{0}\right)$ was calculated by intersecting the linear regression curve obtained with the $x$-axis (Figures 2 and 3). The estimated lag period of GSH permeation for the $5 \mathrm{mg} / \mathrm{mL}$ solution was $66 \mathrm{~min}$ whereas it was $40.6 \mathrm{~min}$ for the $10 \mathrm{mg} / \mathrm{mL}$ solution. These differences are related to the poor detection of GSH with the $5 \mathrm{mg} / \mathrm{mL}$ GSH solution. As we can see in Figure 2, the first time-point 
at which accumulated GSH could be measured corresponds to $120 \mathrm{~min}$ and hence, extrapolation of the regression curve to intersect the $x$-axis lacks required precision (Figure 2).

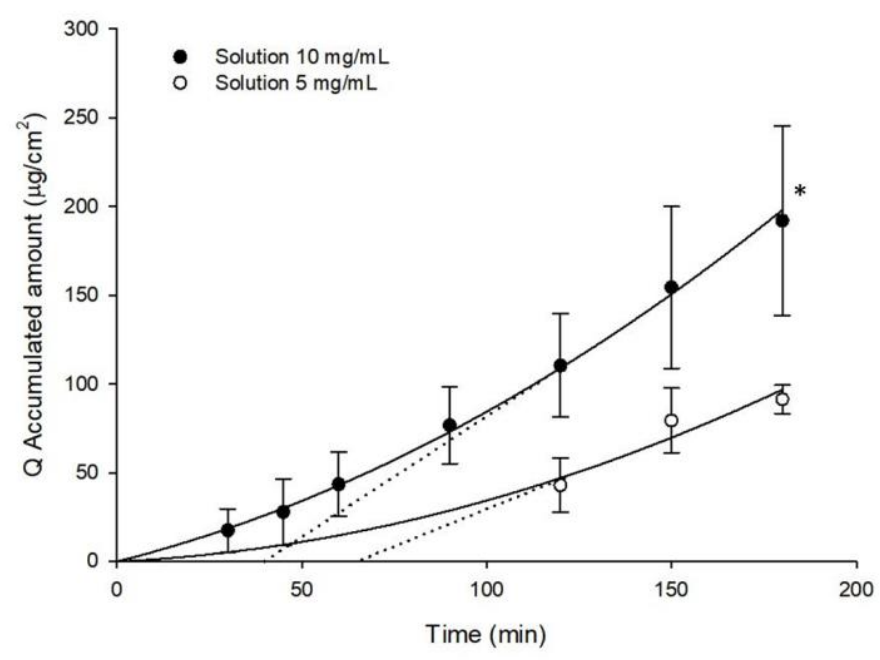

Figure 2. Accumulated amounts of GSH in the receptor compartment $\left(\mathrm{Q}, \mu \mathrm{g} / \mathrm{cm}^{2}\right)$ as a function of time, obtained from samples employed in ex-vivo trans-corneal diffusion studies of different solutions. The dotted line represents the estimated lag time $\left(\mathrm{t}_{0}\right)$ calculated by intersecting with the $x$-axis of the linear regression. (Mean $\pm \mathrm{SD} ; n \geq 3$ ) * $p<0.05$.

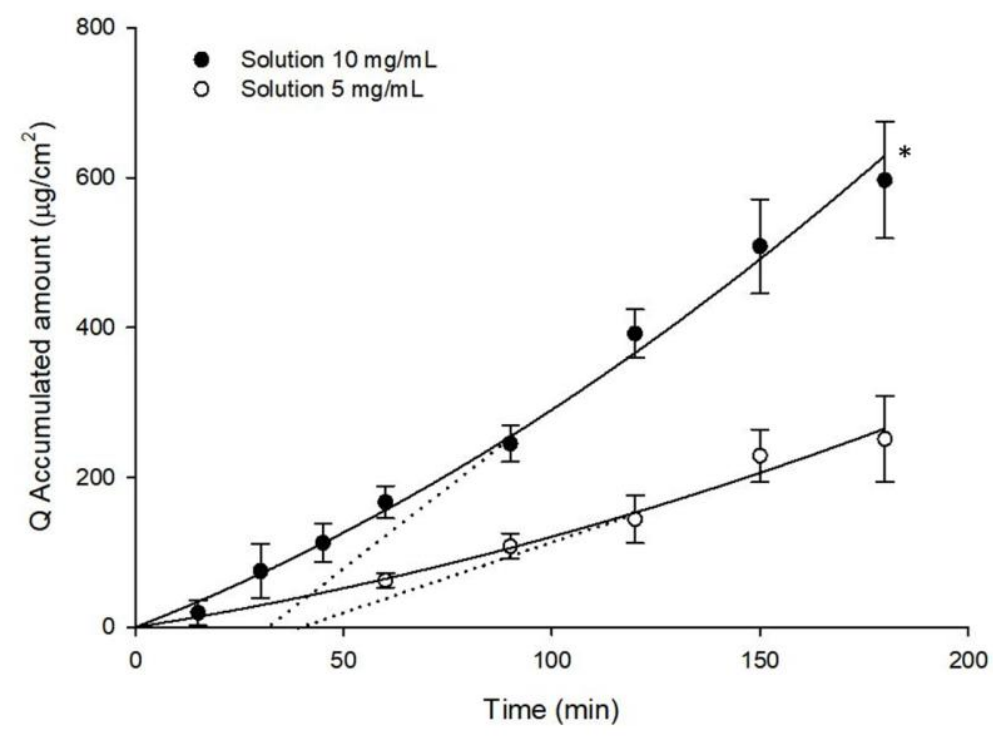

Figure 3. Accumulated amounts of GSH in the receptor compartment $\left(\mathrm{Q}, \mu \mathrm{g} / \mathrm{cm}^{2}\right)$ as a function of time, obtained from samples employed in ex-vivo trans-scleral diffusion studies of different solutions. The dotted line represents the estimated lag time $\left(\mathrm{t}_{0}\right)$ calculated by intersecting with the $x$-axis of the linear regression. (Mean $\pm \mathrm{SD} ; n \geq 3$ ) * $p<0.05$.

The accumulated amounts of GSH in the receptor compartment obtained in ex-vivo trans-scleral diffusion studies carried out with both solutions are shown in Figure 3. Accumulated amounts with $10 \mathrm{mg} / \mathrm{mL}$ solution of GSH were significantly higher than those obtained with the $5 \mathrm{mg} / \mathrm{mL}$ solution of GSH ( $596.74 \pm 78.05 \mu \mathrm{g} / \mathrm{cm}^{2}$ and $251.29 \pm 57.69 \mu \mathrm{g} / \mathrm{cm}^{2}$, respectively; $\left.p<0.05\right)$. For sclera, the estimated lag time for GSH diffusion was $39 \mathrm{~min}$ for the $5 \mathrm{mg} / \mathrm{mL}$ solution and $32.2 \mathrm{~min}$ for the $10 \mathrm{mg} / \mathrm{mL}$ solution. As before, the absence of data (GSH could not be quantified in the earliest part of the curve) may account for the small differences seen in lag-time (Figure-3) As the amount of accumulated GSH in the receptor compartment was significantly higher when the $10 \mathrm{mg} / \mathrm{mL}$ GSH solution was used, 
both in cornea and sclera, the ocular insert was prepared and formulated with a GSH concentration of $10 \mathrm{mg} / \mathrm{mL}$.

A semisolid insert of GSH was formulated in order to develop a controlled delivery system for GSH. Our results show that GSH diffused more efficiently through sclera than through cornea $(p<0.05)$ (Figure 4). The total accumulated amount in the receptor compartment when cornea was used as a membrane was $109.46 \pm 17.61 \mu \mathrm{g} / \mathrm{cm}^{2}$, whereas for sclera the total accumulated GSH was $249.09 \pm 51.17 \mu \mathrm{g} / \mathrm{cm}^{2}$. The estimated lag period for diffusion of GSH when we used the insert was $82.5 \mathrm{~min}$ in cornea and $31.4 \mathrm{~min}$ in sclera.

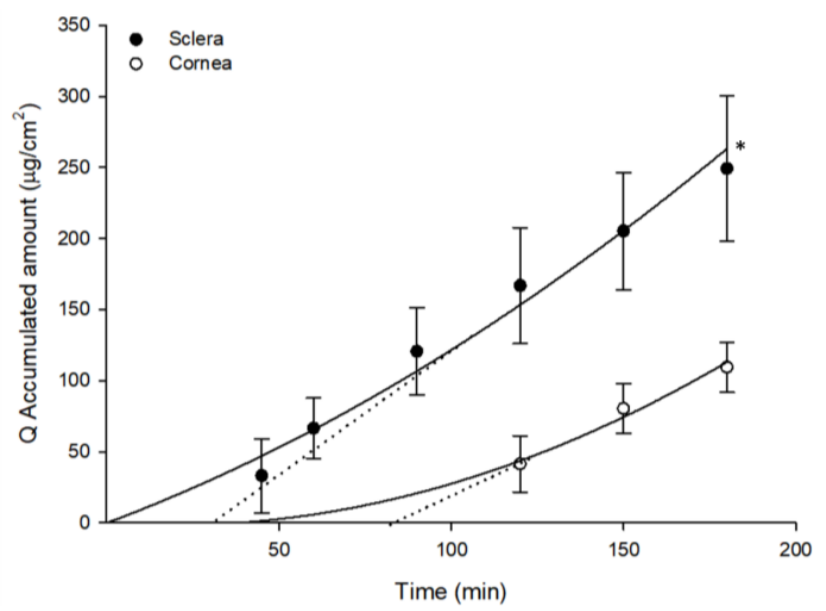

Figure 4. Accumulated amounts of GSH in the receptor compartment $\left(\mathrm{Q}, \mu \mathrm{g} / \mathrm{cm}^{2}\right)$ as a function of time, obtained from samples employed in ex-vivo trans-corneal and trans-scleral diffusion studies with the formulated insert. The dotted line represents the estimated lag time $\left(\mathrm{t}_{0}\right)$ calculated by intersecting with the $x$-axis of the linear regression. (Mean $\pm \mathrm{SD} ; n \geq 3$ ) ${ }^{*} p<0.05$.

The amount of GSH permeating through sclera was greater than that permeating through cornea in the ex-vivo diffusion studies performed with all the formulations assayed $(p<0.05)$ (Figure 5 ). This could be attributed to the different characteristics of the two tissues. The cornea is a complex tissue with five different layers [51]. The outer layer is a stratified squamous non-keratinized epithelium consisting of no less than five layers of cells with varying affinity to hydrophilic and lipophilic molecules [52]. These characteristics, particularly the presence of the corneal epithelium, make diffusion of any hydrophilic molecule across the cornea rather difficult [53]. Histologically, the sclera is composed mainly of collagen fibers [54] forming a dense connective tissue and thus GSH, which is a rather hydrophilic molecule, can permeate through sclera much more easily than it does through cornea.

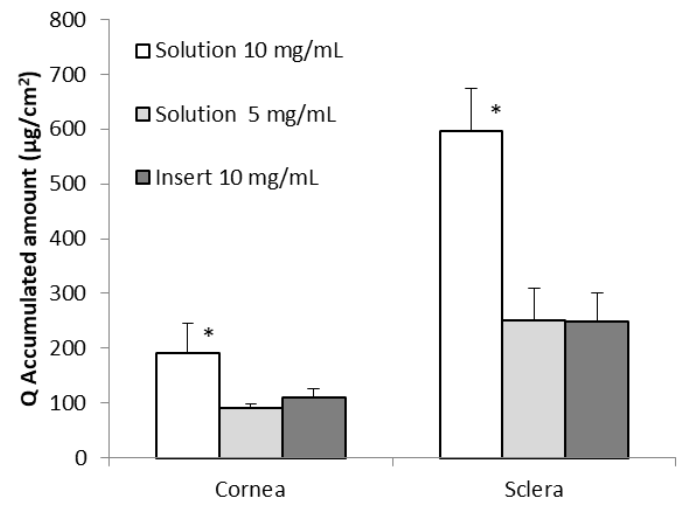

Figure 5. Accumulated amount of GSH in the receptor compartment after $3 \mathrm{~h}$ of experiment $\left(\mathrm{Q}, \mu \mathrm{g} / \mathrm{cm}^{2}\right)$ obtained from samples of ex-vivo trans-corneal and trans-scleral diffusion studies performed with different formulations. (Mean $\pm \mathrm{SD} ; n \geq 3$ ) * $p<0.05$. 
If we focus on the anatomy of the eye, the sclera is only separated from the retina by choroid [23]. Our results suggest that these GSH formulations may be used to target the retinal tissue if we assume that GSH is able to reach the retina despite the choroid being a highly vascularized tissue. In fact, several studies have used different liposomal formulations with pegylated glutathione in order to target retina and other neuronal tissues [55-57].

The highest accumulated GSH values in the receptor compartment were measured when sclera was used as a membrane and a $10 \mathrm{mg} / \mathrm{mL}$ GSH solution was used (Figure 5). Similar accumulated GSH values were measured when a $5 \mathrm{mg} / \mathrm{mL} \mathrm{GSH} \mathrm{solution} \mathrm{or} 10 \mathrm{mg} / \mathrm{mL} \mathrm{GSH}$ in a semisolid insert were used (Figure 5). No statistical differences were found between the values measured in this case $(p<0.05)$.

In order to determine the permeability of GSH through cornea and sclera we calculated the permeability coefficients (Kp) of GSH under the different assay conditions used in ocular diffusion studies (Table 3). Kp values (Table 3) were calculated by means of the following equation.

$$
\mathrm{Kp}=\mathrm{J} / \mathrm{C}
$$

where $\mathrm{Kp}$ is the permeability coefficient of the drug $(\mathrm{cm} / \mathrm{h}), \mathrm{J}$ is flux of GSH though the membrane, obtained from the slope between the accumulated amount of the drug in the receptor compartment $\left(\mathrm{Q}, \mathrm{mg} / \mathrm{cm}^{2}\right)$ versus time $(\mathrm{h})$, and $\mathrm{C}$ is initial concentration of $\mathrm{GSH}$ in the donor compartment $(\mathrm{mg} / \mathrm{mL})$.

Table 3. Permeability coefficient of GSH through cornea and sclera $\left(\mathrm{Kp} \times 10^{3}, \mathrm{~cm} / \mathrm{h}\right)$ using different formulations (Mean $\pm \mathrm{SD} ; n \geq 3) * p<0.05$.

\begin{tabular}{cccc}
\hline \multirow{2}{*}{ Conditions } & \multicolumn{2}{c}{$\mathbf{K p} \times \mathbf{1 0}^{\mathbf{3}} \mathbf{( \mathbf { c m } / \mathbf { h } )}$} \\
\cline { 3 - 4 } & & Cornea & \multicolumn{1}{c}{ Sclera } \\
\hline \multirow{2}{*}{ Solutions } & $5 \mathrm{mg} / \mathrm{mL}$ & $6.08 \pm 0.83$ & $17.63 \pm 3.62{ }^{*}$ \\
& $10 \mathrm{mg} / \mathrm{mL}$ & $6.54 \pm 1.79$ & $20.74 \pm 2.08^{*}$ \\
\hline Insert & $10 \mathrm{mg} / \mathrm{mL}$ & $3.44 \pm 0.64$ & $8.76 \pm 1.58$ \\
\hline
\end{tabular}

The Kp values confirm that permeability of GSH through sclera was significantly higher than through cornea $(p<0.05)$.

In addition, it was found that the permeability coefficient was lower when the insert was used (both in cornea and sclera). This could be a consequence of the liberation of GSH from the insert. However, it would be better to use this formulation because an ocular insert increases the contact time between the formulation and the eye, thus ensuring sustained release during treatment $[28,29]$. There are several possibilities for sterilizing such inserts for in vivo use with ultraviolet light, $\gamma$-irradiation, or filter-sterilization, while maintaining their physicochemical properties and therapeutic value [58-60], so safe application of these inserts to the eye is possible.

Although other research groups have studied the possibility of using progesterone or lipoic acid to increase the production of GSH in the retina [61,62], our suggestion is to administer GSH directly into the eye because it has been previously demonstrated that an increment of GSH in the eye reduces oxidative stress and delays the appearance of eye-related diseases [15,63-66]. The results obtained in this study provide interesting results for the development of ocular formulations of GSH as an antioxidant for the treatment of eye diseases.

\section{Conclusions}

The results from this study have revealed that the GSH solution is not an irritant to ocular mucosa and is stable in solution ( $\mathrm{pH}$ 6.5) preserved at $4{ }^{\circ} \mathrm{C}$ in darkness for up to one month and the incorporation of Vit $\mathrm{C}$ into this solution does not lengthen its preservation. GSH permeated through cornea and sclera, obtaining better results when administered through sclera. 
A semisolid ocular insert of GSH was formulated and its evaluation supports the possibility of developing an ocular controlled delivery system of GSH as an antioxidant treatment for ocular diseases in preference to GSH solutions applied as eye drops. As stated earlier, ocular inserts may provide accurate dosing, reduce administration frequency while diminishing visual and systemic side effects, and increasing compliance [28,29].

In the near future, a new generation of ocular delivery systems for antioxidants may reach the market which could represent a significant advance in the therapy for ocular diseases.

There are some data on the pharmacokinetics of GSH. For example, the GSH half-life determined in vivo in Saccharomyces cerevisiae was found to be around $90 \mathrm{~min}$ [67]. Another study on rats evaluated the pharmacokinetics and distribution of glutathione pegylated liposomes after intravenous and intraperitoneal administration. The area under the curve (AUC) $24 \mathrm{~h}$ after administration for liposomal was $983 \pm 97 \mu \mathrm{g} \mathrm{h} / \mathrm{mL}$ and $665 \pm 118 \mu \mathrm{g} \mathrm{h} / \mathrm{mL}$, respectively [56]. In humans, pharmacokinetic parameters were evaluated after $50 \mathrm{mg} / \mathrm{kg}$ GSH administration by infusion to adults. In this case, the AUC at $240 \mathrm{~min}$ was $1242.8 \mu \mathrm{M}$ min and the GSH half-life was $10.9 \mathrm{~min}$ [68].

Determination of pharmacokinetic parameters in ocular tissues is a major challenge due to the complex anatomy and dynamic physiological barriers of the eye [52,69-72]. In drug development, human pharmacokinetic parameters are generally assessed after intravenous administration followed by plasma sampling at different time intervals. When drugs are administered to or through the eye and they have a local therapeutic effect, sampling is not feasible. Exceptions could be monitoring drug levels from biopsies, or collection and analysis of aqueous humor from patients undergoing ophthalmic surgical procedures [71].

Taking into the account the complexity of the eye and the degradation of GHS at ocular level, in vivo ocular pharmacokinetic studies will need to be conducted to determine the fate of GSH when administered to the eye using the developed ocular formulation. The results obtained in this study provide interesting results for the development of ocular formulations of GSH as an antioxidant for the treatment of eye diseases.

Author Contributions: Conceptualization, M.S.-M., C.B.-F., M.M., and A.L.-C.; methodology, M.S.-M., A.M.A.-C., M.A.C.-P., and V.R.; writing-original draft preparation, M.S.-M., V.R., C.B.-F., M.M., and A.L.-C.; writing-review and editing, M.S.-M., A.M.A.-C., M.A.C.-P., V.R., C.B.-F., M.M., and A.L.-C.; supervision, V.R., M.M., and A.L.-C.; funding acquisition, M.M. and A.L.-C. All authors have read and agreed to the published version of the manuscript.

Funding: This research was funded by Universidad CEU-Cardenal Herrera.

Acknowledgments: The authors acknowledge Corpa's group at Universidad CEU-Cardenal Herrera for kindly donating the rabbit eyes used in this research.

Conflicts of Interest: The authors declare no conflict of interest. The funders had no role in the design of the study; in the collection, analyses, or interpretation of data; in the writing of the manuscript, or in the decision to publish the results.

\section{References}

1. Sies, H. Oxidative stress: From basic research to clinical application. Am. J. Med. 1991, 91, S31-S38. [CrossRef]

2. Vizzarri, F.; Palazzo, M.; Bartollino, S.; Casamassima, D.; Parolini, B.; Troiano, P.; Caruso, C.; Costagliola, C. Effects of an Antioxidant Protective Topical Formulation on Eye Exposed to Ultraviolet-Irradiation: A Study in Rabbit Animal Model. Physiol. Res. 2018, 457-464. [CrossRef] [PubMed]

3. Chen, Y.; Mehta, G.; Vasiliou, V. Antioxidant Defenses in the ocular surface. Ocul. Surf. 2009, 7, $176-185$. [CrossRef]

4. Umapathy, A.; Donaldson, P.; Lim, J. Antioxidant Delivery Pathways in the Anterior Eye. Biomed Res. Int. 2013, 2013, 1-10. [CrossRef]

5. Riley, M.V.; Meyer, R.F.; Yates, E.M. Glutathione in the aqueous humor of human and other species. Investig. Ophthalmol. Vis. Sci. 1980, 19, 94-96.

6. Brubaker, R.F.; Bourne, W.M.; Bachman, L.A.; McLaren, J.W. Ascorbic acid content of human corneal epithelium. Investig. Ophthalmol. Vis. Sci. 2000, 41, 1681-1683. 
7. Koc, M.; Bostanci, B.; Demirel, O.O.; Genc, F.; Tekin, K.; Koban, Y.; Dincel, A.S.; Sen, M.; Yilmazbas, P. The Effect of Ascorbic Acid (Vitamin C) on Transepithelial Corneal Cross-Linking in Rabbits. J. Ocul. Pharmacol. Ther. 2017, 33, 525-529. [CrossRef]

8. Braakhuis, A.; Raman, R.; Vaghefi, E. The Association between Dietary Intake of Antioxidants and Ocular Disease. Diseases 2017, 5. [CrossRef]

9. Meister, A.; Anderson, M.E. Glutathione. Annu. Rev. Biochem. 1983, 52, 711-760. [CrossRef]

10. Kaplowitz, N.; Aw, T.Y.; Ookhtens, M. The regulation of hepatic glutathione. Annu. Rev. Pharmacol. Toxicol. 1985, 25, 715-744. [CrossRef]

11. Meister, A.; Tate, S.S. Glutathione and Related $\gamma$-Glutamyl Compounds: Biosynthesis and Utilization. Annu. Rev. Biochem. 1976, 45, 559-604. [CrossRef] [PubMed]

12. Ballatori, N.; Krance, S.M.; Marchan, R.; Hammond, C.L. Plasma membrane glutathione transporters and their roles in cell physiology and pathophysiology. Mol. Asp. Med. 2009, 30, 13-28. [CrossRef] [PubMed]

13. Tokarz, P.; Kaarniranta, K.; Blasiak, J. Role of antioxidant enzymes and small molecular weight antioxidants in the pathogenesis of age-related macular degeneration (AMD). Biogerontology 2013, 14, 461-482. [CrossRef] [PubMed]

14. Bringmann, A.; Wiedemann, P. Müller glial cells in retinal disease. Ophthalmologica 2012, 227, 1-19. [CrossRef]

15. Sánchez-Vallejo, V.; Benlloch-Navarro, S.; Trachsel-Moncho, L.; López-Pedrajas, R.; Almansa, I.; Romero, F.J.; Miranda, M. Alterations in glutamate cysteine ligase content in the retina of two retinitis pigmentosa animal models. Free Radic. Biol. Med. 2016, 96, 245-254. [CrossRef]

16. Fan, X.; Monnier, V.M.; Whitson, J. Lens glutathione homeostasis: Discrepancies and gaps in knowledge standing in the way of novel therapeutic approaches. Exp. Eye Res. 2017, 156, 103-111. [CrossRef]

17. Lomaestro, B.M.; Malone, M. Glutathione in health and disease: Pharmacotherapeutic issues. Ann. Pharmacother. 1995, 29, 1263-1273. [CrossRef]

18. Bachhawat, A.K.; Thakur, A.; Kaur, J.; Zulkifli, M. Glutathione transporters. Biochim. Biophys. Acta 2013, 1830, 3154-3164. [CrossRef]

19. Izumi, H.; Sato, K.; Kojima, K.; Saito, T.; Saido, T.C.; Fukunaga, K. Oral glutathione administration inhibits the oxidative stress and the inflammatory responses in AppNL-G-F/NL-G-F knock-in mice. Neuropharmacology 2020, 168, 108026. [CrossRef]

20. Sinha, R.; Sinha, I.; Calcagnotto, A.; Trushin, N.; Haley, J.S.; Schell, T.D.; Richie, J.P. Oral supplementation with liposomal glutathione elevates body stores of glutathione and markers of immune function. Eur. J. Clin. Nutr. 2018, 72, 105-111. [CrossRef]

21. Mischley, L.K.; Lau, R.C.; Shankland, E.G.; Wilbur, T.K.; Padowski, J.M. Phase IIb Study of Intranasal Glutathione in Parkinson's Disease. J. Parkinsons Dis. 2017, 7, 289-299. [CrossRef] [PubMed]

22. Sanz, M.M.; Johnson, L.E.; Ahuja, S.; Ekström, P.A.R.; Romero, J.; van Veen, T. Significant photoreceptor rescue by treatment with a combination of antioxidants in an animal model for retinal degeneration. Neuroscience 2007, 145, 1120-1129. [CrossRef] [PubMed]

23. Miranda, M.; Arnal, E.; Ahuja, S.; Alvarez-Nölting, R.; López-Pedrajas, R.; Ekström, P.; Bosch-Morell, F.; van Veen, T.; Romero, F.J. Antioxidants rescue photoreceptors in rd1 mice: Relationship with thiol metabolism. Free Radic. Biol. Med. 2010, 48, 216-222. [CrossRef] [PubMed]

24. Souza, J.G.; Dias, K.; Pereira, T.A.; Bernardi, D.S.; Lopez, R.F. V Topical delivery of ocular therapeutics: Carrier systems and physical methods. J. Pharm. Pharmacol. 2014, 66, 507-530. [CrossRef]

25. Vandervoort, J.; Ludwig, A. Ocular drug delivery: Nanomedicine applications. Nanomedicine 2007, 2, 11-21. [CrossRef]

26. Mundada, A.S.; Shrikhande, B.K. Design and Evaluation of Soluble Ocular Drug Insert for Controlled Release of Ciprofloxacin Hydrochloride. Drug Dev. Ind. Pharm. 2006, 32, 443-448. [CrossRef]

27. Mundada, A.S.; Shrikhande, B.K. Formulation and Evaluation of Ciprofloxacin Hydrochloride Soluble Ocular Drug Insert. Curr. Eye Res. 2008, 33, 469-475. [CrossRef]

28. Rathore, K.; Nema, R. Review on ocular inserts. Int. J. Pharm. Tech. Res. 2009, 1, 164-169.

29. Rathore, K.S.; Nema, R.K. An Insight into Ophthalmic Drug Delivery System. Int. J. Pharm. Sci. Drug Res. 2009, 1, 1-5. [CrossRef]

30. Kalweit, S.; Besoke, R.; Gerner, I.; Spielmann, H. A national validation project of alternative methods to the Draize rabbit eye test. Toxicol. In Vitro 1990, 4, 702-706. [CrossRef]

31. Rodríguez, I.C.; Cerezo, A.; Salem, I.I. Sistemas de liberación bioadhesivos. ARS Pharm. 2000, 1, 115-128. 
32. Ramkanth, S.; Chetty, C. Design and evaluation of diclofenac sodium ocusert. Int. J. PharmTech Res. 2009, 1, 1219-1223.

33. Pawar, P.K.; Katara, R.; Majumdar, D.K. Design and evaluation of moxifloxacin hydrochloride ocular inserts. Acta Pharm. 2012, 62, 93-104. [CrossRef] [PubMed]

34. Chandran, S.; Roy, A.; Saha, R.N. Effect of $\mathrm{pH}$ and formulation variables on in vitro transcorneal permeability of flurbiprofen: A technical note. AAPS PharmSciTech 2008, 9, 1031-1037. [CrossRef]

35. Srirangam, R.; Majumdar, S. Passive asymmetric transport of hesperetin across isolated rabbit cornea. Int. J. Pharm. 2010, 394, 60-67. [CrossRef]

36. Sebastián-Morelló, M.; Calatayud-Pascual, M.A.; Rodilla, V.; Balaguer-Fernández, C.; López-Castellano, A. Ex vivo rabbit cornea diffusion studies with a soluble insert of moxifloxacin. Drug Deliv. Transl. Res. 2018, 8, 132-139. [CrossRef]

37. Kalevar, V. Donor corneae for preservation. A modified dissection technique. Br. J. Ophthalmol. 1968, 52, 695. [CrossRef]

38. Fu, R.C.-C.; Lidgate, D.M. In Vitro Rabbit Corneal Permeability Study of Ketorolac, Tromethamine, a non-Steroidal Anti-Inflammatory Agent. Drug Dev. Ind. Pharm. 1986, 12, 2403-2430. [CrossRef]

39. Majumdar, S.; Hingorani, T.; Srirangam, R.; Gadepalli, R.S.; Rimoldi, J.M.; Repka, M.A. Transcorneal permeation of L- and D-aspartate ester prodrugs of acyclovir: Delineation of passive diffusion versus transporter involvement. Pharm. Res. 2009, 26, 1261-1269. [CrossRef]

40. Okamoto, N.; Ito, Y.; Nagai, N.; Murao, T.; Takiguchi, Y.; Kurimoto, T.; Mimura, O. Preparation of Ophthalmic Formulations Containing Cilostazol as an Anti-glaucoma Agent and Improvement in Its Permeability through the Rabbit Cornea. J. Oleo Sci. 2010, 59, 423-430. [CrossRef]

41. Reed, D.; Babson, J.; Beatty, P.; Brodie, A.E.; Ellis, W.W.; Potter, D.W. High-performance liquid chromatography analysis of nanomole levels of glutathione, glutathione disulfide, and related thiols and disulfides. Anal. Biochem. 1980, 106, 55-62. [CrossRef]

42. Alambiaga-Caravaca, A.M.; Calatayud-Pascual, M.A.; Rodilla, V.; Concheiro, A.; López-Castellano, A.; Alvarez-Lorenzo, C. Micelles of Progesterone for Topical Eye Administration: Interspecies and Intertissues Differences in Ex Vivo Ocular Permeability. Pharmaceutics 2020, 12, 702. [CrossRef] [PubMed]

43. Lorenzo-Veiga, B.; Sigurdsson, H.H.; Loftsson, T.; Alvarez-Lorenzo, C. Cyclodextrin-Amphiphilic Copolymer Supramolecular Assemblies for the Ocular Delivery of Natamycin. Nanomaterials 2019, 9. [CrossRef]

44. Shang, F.; Lu, M.; Dudek, E.; Reddan, J.; Taylor, A. Vitamin C and vitamin E restore the resistance of GSH-depleted lens cells to $\mathrm{H}_{2} \mathrm{O}_{2}$. Free Radic. Biol. Med. 2003, 34, 521-530. [CrossRef]

45. Smuda, M.; Glomb, M.A. Maillard Degradation Pathways of Vitamin C. Angew. Chem. Int. Ed. 2013, 52, 4887-4891. [CrossRef] [PubMed]

46. Du, J.; Cullen, J.J.; Buettner, G.R. Ascorbic acid: Chemistry, biology and the treatment of cancer. Biochim. Biophys. Acta 2012, 1826, 443-457. [CrossRef] [PubMed]

47. Foyer, C.H.; Halliwell, B. The presence of glutathione and glutathione reductase in chloroplasts: A proposed role in ascorbic acid metabolism. Planta 1976, 133, 21-25. [CrossRef]

48. Winkler, B.S.; Orselli, S.M.; Rex, T.S. The redox couple between glutathione and ascorbic acid: A chemical and physiological perspective. Free Radic. Biol. Med. 1994, 17, 333-349. [CrossRef]

49. Van Eyk, A.D.; Seifart, H.I.; Meyer, D.; van der Bijl, P. In Vitro Transcorneal Diffusion of the Antimicrobial Macrolides Azithromycin and Clarithromycin and the Impact on Microbial Keratitis. Cornea 2009, 28, 441-446. [CrossRef]

50. Van Der Bijl, P.; Engelbrecht, A.H.; Van Eyk, A.D.; Meyer, D. Comparative permeability of human and rabbit corneas to cyclosporin and tritiated water. J. Ocul. Pharmacol. Ther. 2002, 18, 419-427. [CrossRef]

51. Tortora, G.J.; Derrickson, B. (Eds.) Principios de Anatomía y Fisiología, 13th ed.; Panamerican: Madrid, Spain, 2013.

52. Gaudana, R.; Ananthula, H.K.; Parenky, A.; Mitra, A.K. Ocular drug delivery. AAPS J. 2010, 12, $348-360$. [CrossRef]

53. Zhang, W.; Prausnitz, M.R.; Edwards, A. Model of transient drug diffusion across cornea. J. Control. Release 2004, 99, 241-258. [CrossRef] [PubMed]

54. Kim, S.H.; Lutz, R.J.; Wang, N.S.; Robinson, M.R. Transport barriers in transscleral drug delivery for retinal diseases. Ophthalmic Res. 2007, 39, 244-254. [CrossRef] [PubMed] 
55. Rotman, M.; Welling, M.M.; Bunschoten, A.; de Backer, M.E.; Rip, J.; Nabuurs, R.J.A.; Gaillard, P.J.; van Buchem, M.A.; van der Maarel, S.M.; van der Weerd, L. Enhanced glutathione PEGylated liposomal brain delivery of an anti-amyloid single domain antibody fragment in a mouse model for Alzheimer's disease. J. Control. Release 2015, 203, 40-50. [CrossRef] [PubMed]

56. Rip, J.; Chen, L.; Hartman, R.; van den Heuvel, A.; Reijerkerk, A.; van Kregten, J.; van der Boom, B.; Appeldoorn, C.; de Boer, M.; Maussang, D.; et al. Glutathione PEGylated liposomes: Pharmacokinetics and delivery of cargo across the blood-brain barrier in rats. J. Drug Target. 2014, 22, 460-467. [CrossRef] [PubMed]

57. Paquet-Durand, F. Degenerating photoreceptors in Retinitis pigmentosa models release cGMP. A way of self protection? In Proceedings of the Research: A Vision for Hpe ARVO 2016, Seattle, WA, USA, 1-5 May 2016.

58. Kumari, A.; Sharma, P.K.; Garg, V.K.; Garg, G. Ocular inserts-Advancement in therapy of eye diseases. J. Adv. Pharm. Technol. Res. 2010, 1, 291-296. [CrossRef]

59. Dekina, S.S.; Romanovskaya, I.I.; Ovsepyan, A.M.; Balashova, M.V. Sterilization of Ocular Medical Inserts with Immobilized Proteins. Pharm. Chem. J. 2015, 49, 275-279. [CrossRef]

60. Naguib, S.S.; Hathout, R.M.; Mansour, S. Optimizing novel penetration enhancing hybridized vesicles for augmenting the in-vivo effect of an anti-glaucoma drug. Drug Deliv. 2017, 24, 99-108. [CrossRef]

61. Miranda, M.; Benlloch-Navarro, S.; Sánchez-Vallejo, V.; Trachsel-Moncho, L.; Soria, J.M.; Almansa, I.; Araiz, J. Effect of glutathione ethyl ester, lipoic acid and progesterone on photoreceptor survival in the retina of $\operatorname{rd} 10$ mice. Investig. Ophthalmol. Vis. Sci. 2014, 55, 1733.

62. Sánchez-Vallejo, V.; Benlloch-Navarro, S.; López-Pedrajas, R.; Romero, F.J.; Miranda, M. Neuroprotective actions of progesterone in an in vivo model of retinitis pigmentosa. Pharmacol. Res. 2015, 99, 276-288. [CrossRef]

63. Cantó, A.; Olivar, T.; Romero, F.J.; Miranda, M. Nitrosative Stress in Retinal Pathologies: Review. Antioxidants 2019, 8, 543. [CrossRef] [PubMed]

64. Miranda, M.; Alvarez-Nölting, R.; Araiz, J.; Romero Gómez, F.J. Antioxidant therapy in retinitis pigmentosa. Nov. Asp. Neuroprot. 2010, 661,1-15.

65. Gomez, F.J.R.; Miranda, M.; Arnal, E.; Ahuja, S.; Garcia-Delpech, S.; Ekström, P.; van Veen, T. Antioxidants Reduce Cell Death in a Model of Retinitis Pigmentosa: Relationship With Glutathione Metabolism. Investig. Ophthalmol. Vis. Sci. 2009, 50, 700.

66. Sancho-Pelluz, J.; Arango-Gonzalez, B.; Kustermann, S.; Romero, F.J.; van Veen, T.; Zrenner, E.; Ekström, P.; Paquet-Durand, F. Photoreceptor Cell Death Mechanisms in Inherited Retinal Degeneration. Mol. Neurobiol. 2008, 38, 253-269. [CrossRef] [PubMed]

67. Baudouin-Cornu, P.; Lagniel, G.; Kumar, C.; Huang, M.-E.; Labarre, J. Glutathione Degradation Is a Key Determinant of Glutathione Homeostasis. J. Biol. Chem. 2012, 287, 4552-4561. [CrossRef]

68. Hong, S.-Y.; Gil, H.-W.; Yang, J.-O.; Lee, E.-Y.; Kim, H.-K.; Kim, S.-H.; Chung, Y.-H.; Hwang, S.-K.; Lee, Z.-W. Pharmacokinetics of Glutathione and Its Metabolites in Normal Subjects. J. Korean Med. Sci. 2005, 20, 721. [CrossRef]

69. Del Amo, E.M.; Rimpelä, A.-K.; Heikkinen, E.; Kari, O.K.; Ramsay, E.; Lajunen, T.; Schmitt, M.; Pelkonen, L.; Bhattacharya, M.; Richardson, D.; et al. Pharmacokinetic aspects of retinal drug delivery. Prog. Retin. Eye Res. 2017, 57, 134-185. [CrossRef]

70. Ranta, V.-P.; Urtti, A. Transscleral drug delivery to the posterior eye: Prospects of pharmacokinetic modeling. Adv. Drug Deliv. Rev. 2006, 58, 1164-1181. [CrossRef]

71. Agrahari, V.; Mandal, A.; Agrahari, V.; Trinh, H.M.; Joseph, M.; Ray, A.; Hadji, H.; Mitra, R.; Pal, D.; Mitra, A.K. A comprehensive insight on ocular pharmacokinetics. Drug Deliv. Transl. Res. 2016, 6, 735-754. [CrossRef]

72. Gunda, S.; Hariharan, S.; Mitra, A.K. Corneal Absorption and Anterior Chamber Pharmacokinetics of Dipeptide Monoester Prodrugs of Ganciclovir (GCV): In Vivo Comparative Evaluation of These Prodrugs with Val-GCV and GCV in Rabbits. J. Ocul. Pharmacol. Ther. 2006, 22, 465-476. [CrossRef]

(C) 2020 by the authors. Licensee MDPI, Basel, Switzerland. This article is an open access article distributed under the terms and conditions of the Creative Commons Attribution (CC BY) license (http://creativecommons.org/licenses/by/4.0/). 